\title{
Does Financial Integration Matter for Financial Development? Evidence from the East Asian and Pacific Region
}

\author{
Farhad Taghizadeh-Hesary ${ }^{1}$, Nguyet Thi Minh Phi ${ }^{2+}$, Hanh Hoang Thi Hong ${ }^{3}$, Vu Tuan Chu ${ }^{4}$ \\ ${ }^{1}$ Tokai University, Japan \\ ${ }^{2}$ Academy of Finance, Vietnam / Centre for Applied Economics and Business Research, Vietnam \\ ${ }^{3}$ Academy of Finance, Hanoi, Vietnam \\ ${ }^{4}$ National Economics University, Vietnam / Centre for Applied Economics and Business Research, Vietnam
}

\begin{abstract}
This paper assesses the impact of financial integration on financial development and establishes thresholds for materializing gains of financial advances from financial globalization using a sample of 34 countries from the East Asian and Pacific region. Following the approaches of Kose et al. (2011) and Asongu and De Moor (2016), we test non-linearity within the financial openness and financial development nexus through semi-parametric ordinary least-squares regression, and then, we develop threshold dynamics models. According to our findings, the effect of financial integration on financial development significantly changes across different financial inflows. When using external debt as a proxy for financial openness, there exists a robust significant inverted U-shaped relationship between financial integration and financial development. The empirical findings also suggest that the financial integration-development nexus is contingent on the level of trade openness, national income, and institutional quality. The results are robust to different measures of financial development and integration, the inclusion of other determinants of financial development, and considerations of endogeneity.
\end{abstract}

Keywords: Financial integration, Financial development, Trade openness, GDP per capita, East Asian and Pacific region

JEL Classifications: F36, F40, O16, O55

Received 6 June 2019, Revised 2 September 2019, Accepted 7 October 2019

\section{Introduction}

The notion "more finance, more growth" is generally supported by many research studies (Arestis et al. 2014, Beck et al. 2000b, Rajan and Zingales 2003, Baltagi et al. 2009, Kose

\footnotetext{
+Corresponding Author: Nguyet Thi Minh Phi

Lecturer, Faculty of Banking and Insurance, Academy of Finance, 58 Le Van Hien, Duc Thang Ward, Bac Tu Liem District, Hanoi, Vietnam, Tel: +84 829010 574, Email: minhnguyetphi.aof@gmail.com

Co-Author: Farhad Taghizadeh-Hesary

Associate Professor of Economics, Tokai University, Address: 2 Chome-28-4 Tomigaya, Shibuya City, Tokyo 151-8677, Japan, Email: farhadth@gmail.com

Co-Author: Hanh Hoang Thi Hong

Lecturer, Faculty of Business Administration, Academy of Finance, Address: 58 Le Van Hien, Duc Thang Ward, Bac Tu Liem District, Hanoi, Vietnam, Tel: +84 981229 391, Email: hanhhth.ec@gmail.com

Co-Author: $\mathrm{Vu}$ Tuan Chu

Lecturer, Faculty of Business Administration, National Economics University, Address: 207 Giai Phong, Dong Tam Ward, Hai Ba Trung District, Hanoi, Vietnam, Tel: +84 934675491, Email: vutuanchu@gmail.com
} 
et al. 2006). However, the 2008 financial crisis revealed that malfunctioning financial systems could result in under-investment and misallocation of resources. Therefore, many have argued that "better finance, more growth" would be more accurate (Law et al. 2013). Increasing attention has been paid in recent years to examine what constitutes better finance.

Financial integration 1 ) is an aspect of advanced financial systems. In theory, the liberalization of financial systems facilitates financial development by ensuring more transparency and competition in the financial sector (Obstfeld 2008), allowing capital and resources to be efficiently allocated (Kose et al. 2009a) and encouraging the formation of best practices of regulation (Kose et al. 2009a). Thus, the liberalization of the financial market contributes to increasing stock market liquidity, improving the efficiency of the banking system (Levine 2001), and reducing the cost of capital (Stultz 1999). However, there is a growing concern that too much integration could be harmful to the development of financial systems. Higher financial openness could lead to excessive risk-taking (Kose et al. 2009a), capital flight, vulnerability to self-fulfilling crises (David et al. 2015), and higher contamination risk among interlinked economies (Kose et al. 2009), eventually imposing detrimental impacts on long-term financial development (Kose et al. 2009). Hence, there is possibly an association between the development of financial systems and integration, which may vary based on the integration levels.

Empirical evidence about the nexus between financial integration and development has never reached a consensus. On the one hand, the first strand of research (Levine 2001, Klein and Olivei 2008, Baltagi et al. 2009, Ozkok 2015, T.-H. Le et al. 2017) documented a positive linkage between the openness of financial sector and its development. For instance, Baltagi et al. (2009), using a broad sample of countries, provided evidence regarding financial integration being an important catalyst for banking sector development. Similarly, Klein and Olivei (2008) found that financial liberalization is linked to greater financial sector depth, regardless of economic settings. Levine (2001) proved that liberalizing restrictions on international portfolio flows could improve stock market liquidity and that the efficiency of a banking system could be enhanced by a stronger presence of foreign banks in the domestic market.

On the other hand, another strand of literature revealed weak or no direct links between financial openness and development. Both Menya et al. (2014) and David et al. (2015) showed that financial integration had no developmental effects on most African countries in their sample. Furthermore, Hauner et al. (2013) and Ashraf (2018), while emphasizing the role of trade openness for financial development, found no evidence of a financial integration effect. Instead, they found that financial account liberalization could force credit providers to increase risk-taking owing to intense credit-market competition. In such a scenario, the costs of higher risk-taking

1) Financial integration generally refers to a country's approach toward restrictions on capital and current account transactions. In this study, the terms "financial integration," "financial openness," "financial engineering," and "financial liberalization" are used interchangeably. 
to the financial sector could outweigh the benefits associated with larger volume and lower credit costs. Rodrik and Subramanian (2009) concluded that in the wake of the sub-prime financial crisis, claims that recent financial engineering generated large gains sounded less plausible.

The explanations for these inconclusive results are threefold. First, previous studies have considered different elements of financial system. Baltagi et al. (2009) and Ashraf (2018) examined the linkage within the banking sector and produced opposite findings. Meanwhile, Demetriades and Law (2006) and Chinn and Ito (2006) focused on equity and stock markets. Ozkok (2015) provided a comprehensive look at most financial system components, including banking, bond, and stock markets.

Second, extant literature has relied on different measurements of financial integration and development. Regarding financial development, finance-growth literature has suggested numerous indicators. For instance, money aggregates (e.g., M2 and M3) as a ratio of Gross Domestic Product (GDP) (Odhiambo 2008) are traditionally used. However, the superiority of these indicators has been questioned because they underestimate the contributions of foreign funds in the financial system. An additional popular measure of financial development is the ratio of liquid liabilities in the financial system to GDP (King and Levine 1993). Nevertheless, it is believed to overestimate economies with underdeveloped financial markets (T.-H. Le et al. 2017). Other standard measures are the ratios of private domestic credit provided from deposit banks and those from financial institutions to GDP (King and Levine 1993). These indicators, however, are criticized for focusing solely on private sector claims (Beck et al. 2000a). In recent literature, a composite index of financial development constructed from different finance indicators has been largely used (David et al. 2015, Ozkok 2015, T.-H. Le et al. 2017) to capture the multidimensional nature of the financial sector rather than solely focusing on one aspect.

Financial integration, as summarized in Kose et al. (2006), has been widely measured by two broad measures: de jure and de facto. De jure measurements (Quinn 2003, Mody and Murshid 2004) evaluate the integration level of a financial market on the basis of the removal of legal restrictions and controls on capital accounts. However, these measures have long been criticized for their over-reliance on the degree of restriction abolishment related to foreign exchange transactions (Kose et al. 2006). In addition, they do not consider the extent of integration into the global markets. Whereas, de facto indicators observe countries' actual integration into the world financial markets through flow and stock variables, including foreign direct investment (\% of GDP) (Asongu and De Moor 2016), portfolio investment flows (\% of GDP) (Kose et al. 2011), and international debt issues (\% of GDP) (Kose et al. 2011). Literature on financial flows distinguishes foreign direct investment (FDI) from portfolio and debt flows (Kose et al. 2011). It is widely believed that the former generates more indirect benefits than debt. 
Finally, the financial integration-development nexus is contingent upon certain conditions of national and institutional development2) (Rodrik and Subramanian 2009, David et al. 2015, Asongu and De Moor 2016). Industrialized countries with more stable macro conditions and developed financial markets have been the main beneficiaries of financial globalization (Kose et al. 2011). Although developing countries have experienced robust economic growth, many are still lagging behind in terms of financial system advances (David et al. 2015). This difference between countries can be largely explained through differences in institutional quality (Law et al. 2013), macroeconomic policies (Boyd et al. 2001), levels of trade openness (Do and Levchenko 2004), population density (Allen et al. 2012), and national income (Jaffee and Levonian 2001).

Currently, a major debate surrounds the idea that certain thresholds of national and institutional development need to be met by an economy for its financial sector to benefit from its greater global integration. Attempts have been made to assess these thresholds in the finance-growth nexus. For example, Yilmazkuday (2011) found that the magnitudes of finance-growth relationship varied according to levels of trade openness and per capita income. Accordingly, high-income countries perhaps need lower levels of trade openness for the benefits of financial development on economic growth to be promoted. By contrast, higher levels of trade openness are required for low-income countries to obtain similar results. Moreover, the catch-up effects via the finance-growth nexus are higher for moderate per capita income levels. Furthermore, Kose et al. (2011), Law et al. (2013), and David et al. (2015) found that the effects of international financial integration were more pronounced for financial development in countries with better institutional quality. However, thresholds for the financial integration and development nexus have been underlooked in the extant literature.

The East Asian and Pacific region has become the main growth driver of the global economy in recent years (World Bank 2017). Most countries in this region follow export-led growth strategies and thus demonstrate superior trade integration (Fry-McKibbin et al. 2018) and financial integration (Boubakri and Guillaumnin 2015). Nevertheless, economies in the region are diverse as regards financial sector development. According to the World Economic Forum's (2012) Financial Development Report, as of 2012, Singapore scored well in financial stability, foreign exchange, derivatives, and equity markets, but they lacked a well-developed bond market and strong financial information disclosure assurances. Meanwhile, Hong Kong had an efficient banking system but performed less effectively in public debt management. By comparison, the financial systems of Vietnam, Laos, and Mongolia remain underdeveloped with a lack of liquidity, low auditing and accounting standards, low transparency, and inadequate financial structure (Didier et al. 2017). These dynamic and diverse development patterns make the region

2) National development is the progression from simple living conditions to more complex ones. It is defined by the 3-dimensional enhancement of economic, environmental, and social indicators. 
an interesting case with which to revisit the nexus of financial engineering and development.

The central objectives of this paper are to empirically examine the financial integration and development nexus in a sample of 34 countries from the East Asian and Pacific region during 1996 2017. To this end, we aim to answer two broad questions. First, does a nonlinear relationship between financial integration and development exist in the East Asian and Pacific region? Second, are there prerequisite threshold conditions that countries in the region need to reach? For the latter question, we focus on three threshold variables: trade openness, national income level, and institutional quality.

We apply two research approaches. First, following Asongu and De Moor (2016), we use a standard semi-parametric approach to test for the existence of $U$ - or inverted U-shaped relationships. Generalized method-of-moments (GMM) estimation is employed to deal with endogeneity issues in this econometrics research. Inspired by Kose et al. (2011), we use fixed effect techniques for consistency checking. We develop a dynamic panel threshold model to find the threshold conditions of national development for the rewards of financial integration on financial development to take effect. Details of these techniques are provided in Section III.B. To our knowledge, this is the first study to combine these two approaches to investigate non-linearity within the financial liberalization and development nexus.

Regarding finance measurements, as noted by Kose et al. (2009a), the influence of financial globalization may vary significantly, depending on the types of external assets and liabilities used. Thus, in this paper, when measuring financial integration, we distinguish between FDI inflows and external debt. This allows us to account for possible differences in the nature and threshold conditions of different types of cross-border flows. Regarding dependent variables, we were inspired by David et al. (2015), Ozkok (2015), and Le et al. (2017) to use principle component analysis to construct an indicator of financial development. This method enables us to capture different attributes of financial sectors, providing more comprehensive analyses and plausible thresholds for policy implications. Details of this technique are discussed in Section III.A. 1

To this end, we contribute to the existing literature in various ways. First, finance literature has primarily focused on the financial development-growth nexus. Thus, we are among the few studies to investigate the nonlinear relationship between financial integration and sector development. Second, we provide a relatively comprehensive overview of the nexus by employing various financial integration measurements and a composite finance indicator to proxy the financial development in a broad sense. Lastly, we account for the role of trade openness, national income, and institutional quality in financial development, an issue that has not been thoroughly examined.

The remainder of this paper is structured as follows. Section II provides information on data and methodology. Section III presents the empirical findings, and Section IV concludes 
with a final discussion and direction for further research.

\section{Methodology}

This section specifies the methodology used in this study to investigate the financial integration and development nexus and the necessary national conditions through which a country could benefit from financial openness.

\section{A. Data and sample}

Our panel dataset includes 34 countries (Appendix 1) from the East Asian and Pacific region for the period 1996 2017. Details of all variables and their sources are provided in Appendix 2.

\section{Dependent variables}

As discussed in the Introduction, literature on this matter has introduced several single ratios, such as money aggregates (e.g., M2 and M3) to GDP, liquid liabilities in the financial system, and private domestic credit, provided from deposit banks and institutions as shares of GDP. However, these measures only serve as rough estimates and offer information on a particular aspect of the financial sector. Given that the financial sector comprises a variety of financial institutions, markets, and products, and that financial development is a multidimensional concept, the adoption of a single variable cannot fully capture all aspects of financial development.

In this study, we follow a number of prior studies to address this shortcoming (David et al. 2015, Ozkok 2015, T.-H. Le et al. 2017) and employ an array of variables related to financial development to construct an aggregate index. Because most countries in our sample are bank dominated and statistics on central and commercial banks are more readily available compared with those on stock and bond markets (T.-H. Le et al. 2017), the financial indicators primarily associated with bank sector development are considered in the present study. Specifically, finance ratios, including broad money supply to GDP, liquid liabilities to GDP, private domestic credit from deposit banks, and private domestic credit from financial institutions to GDP are used. By combining different measures of financial development into a single index, we aim to summarize the comprehensive nature of the financial sector as opposed to focusing on a single aspect. Our composite index helps avoid conflicting results owing to the adoption of individual variables from the literature (Ozkok 2015) and allows for the examination of the multifaceted nature of financial system, which individual variables do not capture (Abiad and Mody 2005).

For creating our financial development index (FIN_DEVELOPMENT), we adopt principal 
component analysis (PCA) (David et al. 2015, Ozkok 2015, T.-H. Le et al. 2017). PCA is a simple and effective method that reduces a dataset to lower dimensions while retaining as much information from the original set as possible. It also helps mitigate multi-collinearity.

Table 1 provides information on PCA for our financial development index. In this analysis, we use the first component criterion to decide how many components to retain. Components with Eigen values greater than 1 are selected.

Table 1. Principal component analysis for financial development index (1996 2017)

\begin{tabular}{ccc}
\hline Principle component & Eigenvalue & Cumulative (\%) \\
\hline Component 1 & 3.030 & 0.757 \\
Component 2 & 0.817 & 0.962 \\
Component 3 & 0.133 & 0.995 \\
Component 4 & 0.020 & 1.000 \\
\hline
\end{tabular}

(Note) Extraction method: Principal component analysis

(Source) Authors' compilation

The Eigen value in Table 1 indicates that the first principal component is a more relevant measure of financial development. Thus, only information related to the first component is considered to form a composite indicator. The financial development index (FIN_DEVELOPMENT) is obtained by averaging component finance indicator corresponding to the factor score coefficient.

Table 2. Component score coefficient matrix (1996 2017)

\begin{tabular}{lc}
\hline \multicolumn{1}{c}{ Variables } & Component 1 (factor score coefficient) \\
\hline Private domestic credit from financial institutions (\% of GDP) & 0.5459 \\
Private domestic credit from deposit banks (\% of GDP) & 0.2942 \\
Liquid liabilities (\% of GDP) & 0.5537 \\
Broad money supply (\% of GDP) & 0.5557 \\
\hline
\end{tabular}

(Note) Extraction method: Principal component analysis

(Source) Authors' compilation

\section{Financial integration indicators}

Owing to their ignorance of the extent of financial system integration, de jure measurements do not fully reflect the degree of financial openness. However, de facto measures, which possibly involve measurement errors, remain the superior measurement of financial integration (Kose et al. 2006) and have been widely used in the literature (Rodrik and Subramanian 2009, Kose et al. 2011, Ozkok 2015, Asongu and De Moor 2016). Therefore, we rely on de facto measurements as proxies for financial integration, including FDI inflows as a share of GDP (\%) (FDIItoGDP) and the ratio of external debt to GDP (\%) (EXDEBTtoGDP). 
The use of FDI inflows as a proxy for financial integration has been largely performed in finance literature (Rodrik and Subramanian 2009, Ozkok 2015, Asongu and De Moor 2016). FDI inflows comprise equity capital, reinvestment of earnings, and other long-term capital (World Bank 2007). As most countries in our sample are developing economies, FDI inflows prove to be more significant than outflows. Thus, we focus on the impact of the inward flows of FDI rather than that of outward or aggregate flows.

The literature on financial flows also distinguishes FDI from portfolio flows and debt (Kose et al. 2011). When debt liabilities constitute the primary form of financial integration, the risks of financial integration seem to be higher. Moreover, the 2008 sub-prime financial crisis and the ongoing public debt crisis reveal that more attention needs to be placed on external debt. Thus, it is worth looking further at the impact of external debt on financial development. In our study, external debt stocks are the sum of public, publicly guaranteed, and private non-guaranteed long-term debt, International Monetary Fund (IMF) credit, and short-term debt (World Bank 2007).

\section{Threshold variables and other control variables}

This study aims to assess prerequisite conditions that a country should reach before the rewards of financial openness can materialize. For each threshold category, we must choose an appropriate measure that is conceptually sound and for which data for our broad sample of countries are available. Therefore, we focus on three indicators: trade openness (TRADE OPENNES ${ }^{3)}$ ); per capita GDP (current international US dollar) in logarithm form (GDPPC), indicating the level of a country's income; and institutional quality $\left(I Q^{4}\right)$ ). The literature suggests that these variables are inextricably related to the levels of integration of the financial market (Kose et al. 2011, Lane and Milesi-Ferreti 2017). Moreover, our study employs INFLATION, which captures the degree of variation in consumer price inflation as a control variable. High inflation is speculated to discourage financial intermediation (Mishkin 2009, Boyd et al. 2001) and can be used as a proxy for macroeconomic policies.

Descriptive statistics for the main variables are reported in Table 3, and a correlation matrix is provided in Table 4 .

3) Measured by the sum of exports and imports of goods and services, expressed as a ratio to GDP

4) In line with previous literature (Kose et al. 2011, T.-H. Le et al. 2017), we computed institutional quality index (IQ) by averaging together six dimensions of governance obtained from the World Bank's Worldwide Governance Indicators (WGI): voice and accountability, political stability and absence of violence, government effectiveness, regulatory quality, rule of law, and control of corruption. 
Table 3. Descriptive statistics

\begin{tabular}{lcccccc}
\hline Variable & No. of obs. & Mean & Median & St. Dev. & Max & Min \\
\hline FIN_DEVELOPMENT & 453 & 139.302 & 112.655 & 82.044 & 389.593 & 26.486 \\
EXDEBTtoGDP & 344 & 46.274 & 38.467 & 36.704 & 246.628 & 0 \\
FDIItoGDP & 641 & 5.073 & 2.568 & 12.892 & 217.920 & -56.465 \\
TRADE OPENNESS & 601 & 112.847 & 100.240 & 78.946 & 442.620 & 0.167 \\
INFLATION & 584 & 4.9614 & 3.032 & 8.967 & 125.272 & -4.009 \\
GDPPC & 663 & 8.952 & 8.623 & 1.206 & 11.850 & 6.584 \\
IQ & 734 & 0.156 & 0.155 & 0.841 & 1.862 & -1.752 \\
\hline
\end{tabular}

Table 4. Correlation matrix

\begin{tabular}{lccccccc}
\hline & $\mathbf{( 1 )}$ & $\mathbf{( 2 )}$ & $\mathbf{( 3 )}$ & $\mathbf{( 4 )}$ & $\mathbf{( 5 )}$ & (6) & (7) \\
\hline (1) FIN_DEVELOPMENT & 1 & & & & & & \\
(2) FDIItoGDP & 0.03 & 1 & & & & & \\
(3) EXDEBTtoGDP & -0.28 & -0.03 & 1 & & & & \\
(4) TRADE OPENNESS & 0.1 & 0.65 & -0.09 & 1 & & & \\
(5) INFLATION & -0.34 & -0.02 & 0.39 & -0.12 & 1 & & \\
(6) GDPPC & 0.63 & 0.11 & -0.15 & 0.33 & -0.32 & 1 & \\
(7) IQ & 0.58 & 0.1 & -0.11 & 0.32 & -0.34 & 0.69 & 1 \\
\hline
\end{tabular}

\section{B. Methodology}

\section{Baseline regressions}

To better examine the relationship between financial integration and development based on the theoretical arguments presented above, this study proposes the following empirical model:

$$
F D_{i t}=\delta_{0}+\delta_{1} F I_{i, t}+\delta_{2}^{j} X_{i, t}^{j}+\varepsilon_{i t}
$$

where $F D_{i t}$ represents financial market development of a country $i$ in year $t$, and $F I_{i t}$ denotes the extent of financial market integration. Specifically, FI is measured via FDIItoGDP and EXDEBTtoGDP. $X_{i, t}^{j}=$ a set of control variables for country $i$ in year $t$ (GDPPC; INFLATION; TRADE OPENNESS, and IQ). $\varepsilon_{i t}$ is an idiosyncratic error term. To investigate the nonlinear relationship between financial integration and development, we add the quadratic term of financial integration in Eq. (1.1). Thus, the new model takes the following form:

$$
F D_{i t}=\delta_{0}+\delta_{1} F I_{i, t}+\delta_{2} F I_{-} \text {square }_{i, t}+\delta_{2}^{j} X_{i, t}^{j}+\varepsilon_{i t},
$$

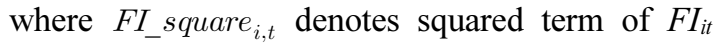

We adopt an endogeneity-robust GMM (Arellano and Bover 1995, Blundell and Bond 1998) 
as an empirical strategy because it is preferred for difference estimation (Bond et al. 2001, p.3-4), in the sense that it mitigates small sample biases from the previous version. Moreover, this approach does not eliminate cross-country variations and controls for potential endogeneity in our regressions. Furthermore, instead of using one-step system GMM, this study employs an extension (i.e., two-step GMM) developed by Roodman (2009), who defines two-step system GMM as being more efficient and robust to heteroscedasticity and autocorrelation problems in econometrics research. In addition, we provide basic fixed effects estimates for consistency checking.

\section{Panel threshold regression (PTR)}

To examine the potential presence of thresholds in some selected prerequisite conditions from which the rewards of financial openness can materialize, we use the threshold regression approach suggested by Hansen (2000). This approach leverages compare-and-contrast analysis of the single- and multiple-threshold models, and in this study, we adopt both models.

The single-threshold model takes the following form:

$$
F D_{i t}=\mu_{i}+\theta X_{i, t}^{j}+\beta_{1} F I_{i t}\left(T H_{i t}<c\right)+\beta_{2} F I_{i t}\left(T H_{i t} \geq c\right)+\varepsilon_{i t},
$$

where $F D_{i t}$ represents financial market development of country $i$ in year $t, \mu_{i}$ is the fixed effect by country, $X_{i, t}^{j}$ are control variables ${ }^{5)}, F I_{i t}$ denotes the financial market integration of a country $i$ in year $t, T H_{i t}$ are threshold variables, and $c$ is an unknown threshold parameter. The sign of regression coefficients $\beta_{1}$ and $\beta_{2}$ changes the impact of financial openness on dependent variables below and above threshold $c . \varepsilon_{i t}$ is an idiosyncratic error term.

The double-threshold model takes the following form:

$$
F D_{i t}=\mu_{i}+\theta X_{i, t}^{j}+\beta_{1} F I_{i t}\left(T H_{i t}<c_{1}\right)+\beta_{2} F I_{i t}\left(c_{1} \leq T H_{i t}<c_{2}\right)+\beta_{3} F I_{i t}\left(T H_{i t} \geq c_{2}\right)+\varepsilon_{i t},
$$

where $c_{1}$ and $c_{2}$ are two unknown threshold parameters. The sign of regression coefficients $\beta_{1}, \beta_{2}$, and $\beta_{3}$ changes the impact of financial openness on dependent variables below threshold $c_{1}$, between $c_{1}$ and $c_{2}$, and above threshold $c_{2}$.

Panel threshold regression (PTR) is a simple and straightforward method of capturing nonlinear behavior of finance phenomena (Hansen 2000). Additionally, this method includes several desirable extensions in comparison to other least-squared estimation techniques, including allowing

5) For threshold variable being trade openness, control variables are GDPPC in logarithm form, inflation and institutional quality. For threshold variable being GDPPC (in logarithm form), control variables are trade openness, inflation and institutional quality. For threshold variable being institutional quality, control variables are GDPPC in logarithm form, inflation and trade openness 
for asymptotic distribution, non-linearity, and endogenous variables (Hansen 1999).

PTR notably requires a strictly balanced dataset. Therefore, the adoption of this technique should significantly reduce our sample size 6 ). With our limited number of observations, we use bootstrap methods to increase the reliability of our hypothesis (Mackinnon 2002). Furthermore, we employ Eicker-Huber-White standard errors to remove the problem of heteroscedasticity that can cause bias to our estimators. The resampling technique is applied 1,000 times to generate empirical $t$-statistics, and we use them to test for the statistical significance of the regression coefficients.

\section{Empirical Results}

\section{A. Financial integration and financial development nexus}

\section{Baseline analyses}

Table 5 shows the ordinary least-squares regressions with fixed effect (FE) and GMM estimations. Columns (1) and (2) present our baseline results without main explanatory variables. Columns (3), (4), (7), and (8) report estimation outcomes of Eq. (1.1) with FDIItoGDP and EXDEBTtoGDP being the variables of main interest. Finally, columns (5) and (6) and columns (9) and (10) provide estimated results of Eq. (1.2) with quadratic terms of FDIItoGDP (FDIItoGDP*square) and EXDEBTtoGDP (EXDEBTtoGDP*square).

Based on the three information criteria, we assess the validity of the estimated outcomes. First, the null hypothesis of the first-order Arellano and Bond autocorrelation test (AR(1)) should be rejected. Second, the null hypothesis of the second-order autocorrelation $(\operatorname{AR}(2))$ for the absence of autocorrelation in the residuals should not be rejected. Thus, from the data presented in Table 5, it is clear that our models do not have an autocorrelation problem. Third, the Hansen $J$-test should not be significant because the null hypothesis states that the instruments are valid. As such, the instruments in our models are valid, as evidenced by their high $p$-value across models. Moreover, to restrict identification and limit the proliferation of instruments, we ensured that the number of instruments was lower than the number of groups in all models.

In columns (1) and (2), most control variables, except institutional quality, are reported to have a significant impact on the dependent variable. In line with the current literature (Asongu and De Moor 2016), significant positive relationships with financial development are found in trade openness and GDP per capita in both estimations. Based on GMM estimations, inflation has a significant negative correlation with financial development, similar to the empirical findings of Boyd et al. (2001). Notably, institutional quality is positively correlated with financial

6) Details of countries included in the PTR are provided in Appendix 2 


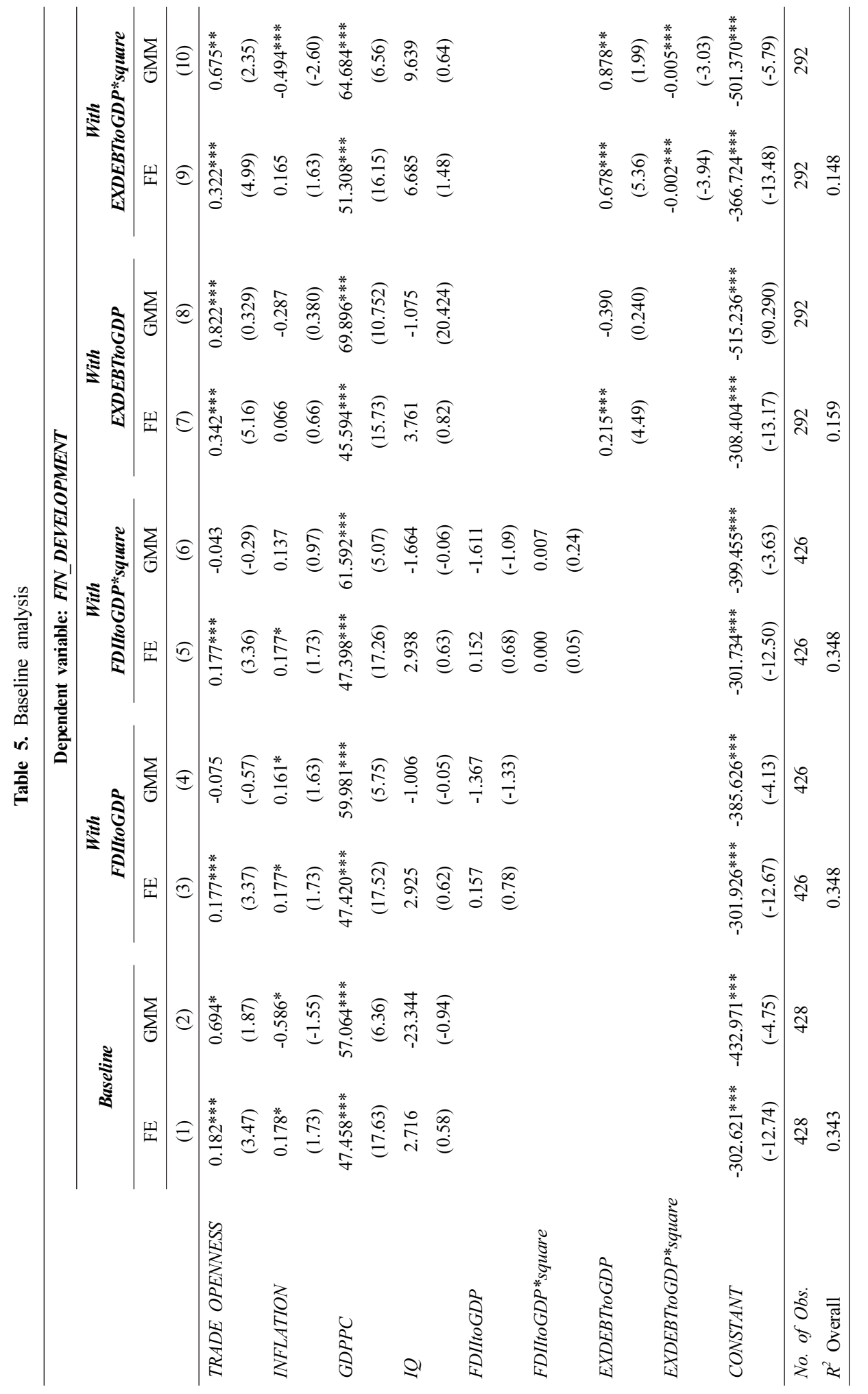




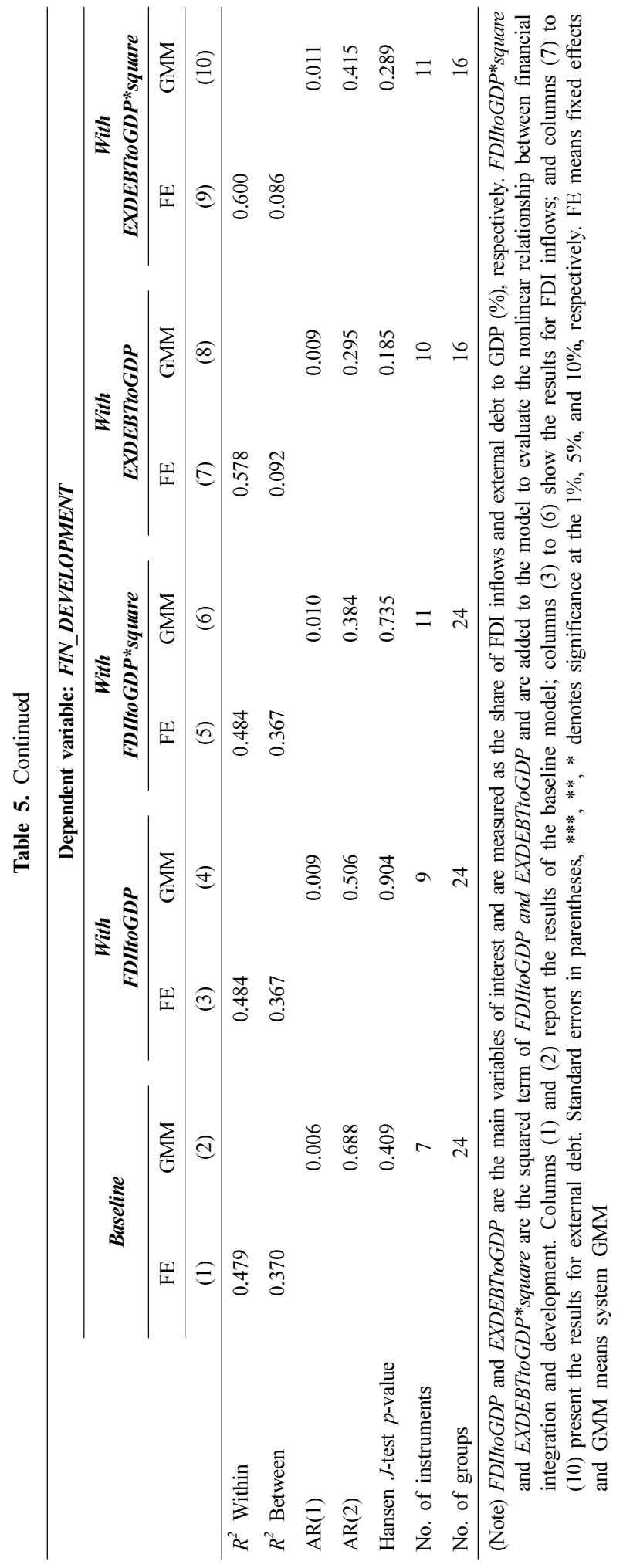


development. Yet, the impact is insignificant, which is in line with the findings of David et al. (2015). The lack of significance of institutional quality could be attributable to the overall low level of institutional development in the examined countries. Otherwise, its effect can be assumed to have been overshadowed by that of GDP per capita.

From columns (3) to (6), the signs and significance of the control variables are generally unchanged compared with those observed in the preceding models. However, the coefficient interactions of FDI inflows and the squared term with financial development are all insignificant. Generally, our findings are in line with those of Asongu and De Moor (2016) who reported insignificant impact of FDI flows on both financial depth and banking sector on the full sample.

Conversely, as shown in the models from column (7), when we use external debt inflows to account for financial integration, another picture is captured. Generally, FE and system GMM estimation methods produce consistent outcomes. External debt can boost financial development as evidenced by its robustly positive coefficients. Furthermore, coefficients on almost all other control variables are significant and consistently report their expected signs.

When the quadratic relationships are considered, significantly negative signs appear in both FE and GMM estimations, indicating that there is an inverted U-shaped relationship between financial openness and development. Accordingly, there is a diminishing marginal effect to the negative threshold of $87.8 \%(0.878 /(2 * 0.005))$. In other words, more external debts will initially boost financial development until it reaches $87.8 \%$ of GDP. Subsequently, the positive effect of debt liabilities to financial development decreases, implying that more cross-border debts would be harmful to the financial system.

\section{Robustness check}

To assess the robustness of the results obtained, we test a number of alternative specifications. First, we consider specifications that include additional regressors identified in the literature as potentially associated with financial development: government expenditure7) (GOV_EXPENDITURE), population density ${ }^{8}$ (POP_DENSITY), public investment ${ }^{9}$ ) (PUB_INVESTMENT), and foreign aid10) (FOREIGN AID). The results of these regressors are reported Table 6. The inclusion of the additional explanatory variables does not change the basic findings presented in Table 5 . Furthermore, the additional control variables do not present coefficients that are statistically significantly different from zero in most specifications.

7) Government expenditure is general government final consumption expenditure as a share of GDP. Inflation and government expenditure add up to macro policies.

8) Population density is measured by dividing the total population by the total area. It provides information on a country's size and market potential.

9) Public investment is measured by gross public investment as a ratio to GDP

10) Foreign aid is total net official development assistance to GDP. Foreign aid is required to reduce the investment-financing gap that less developed countries face. 


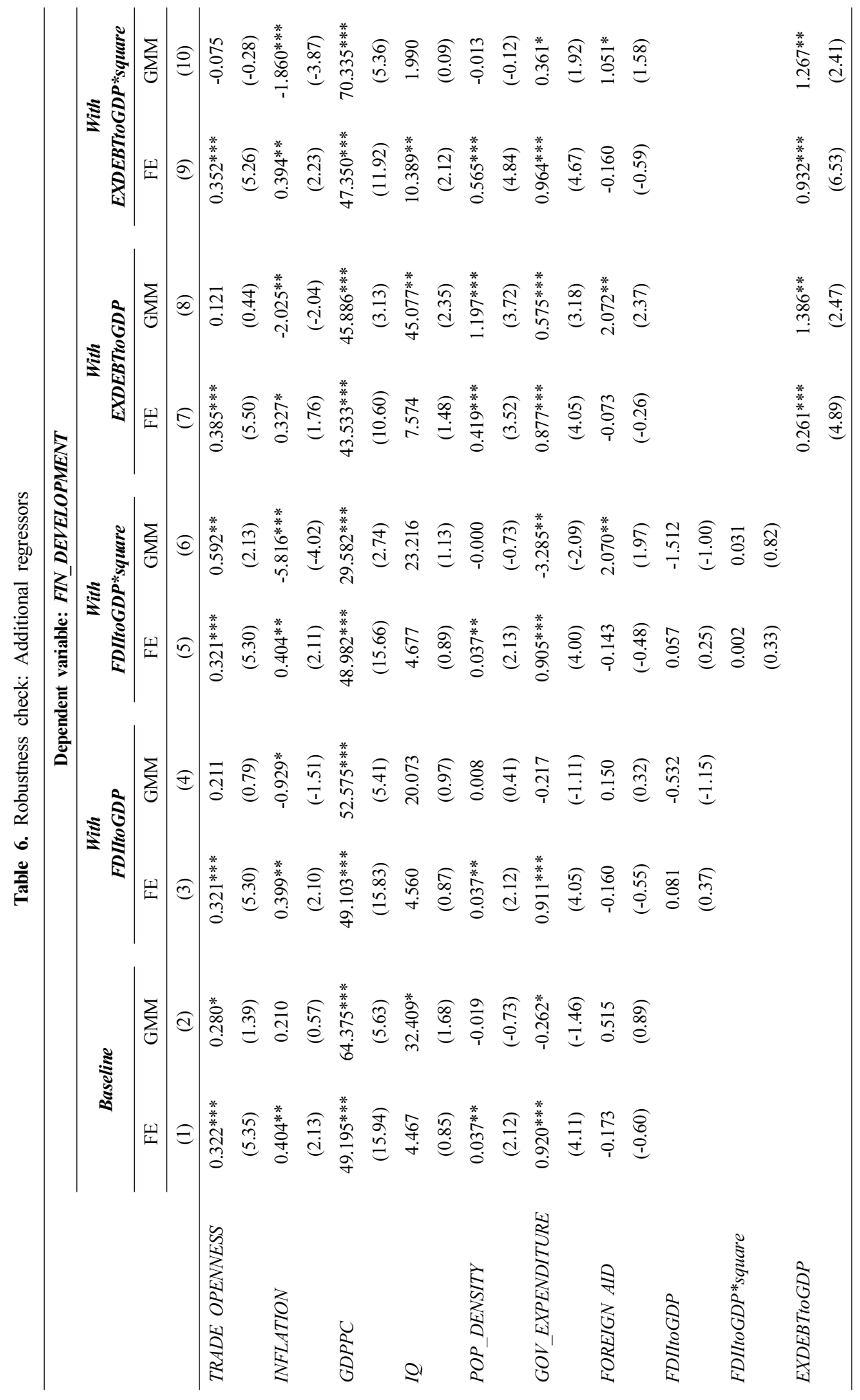




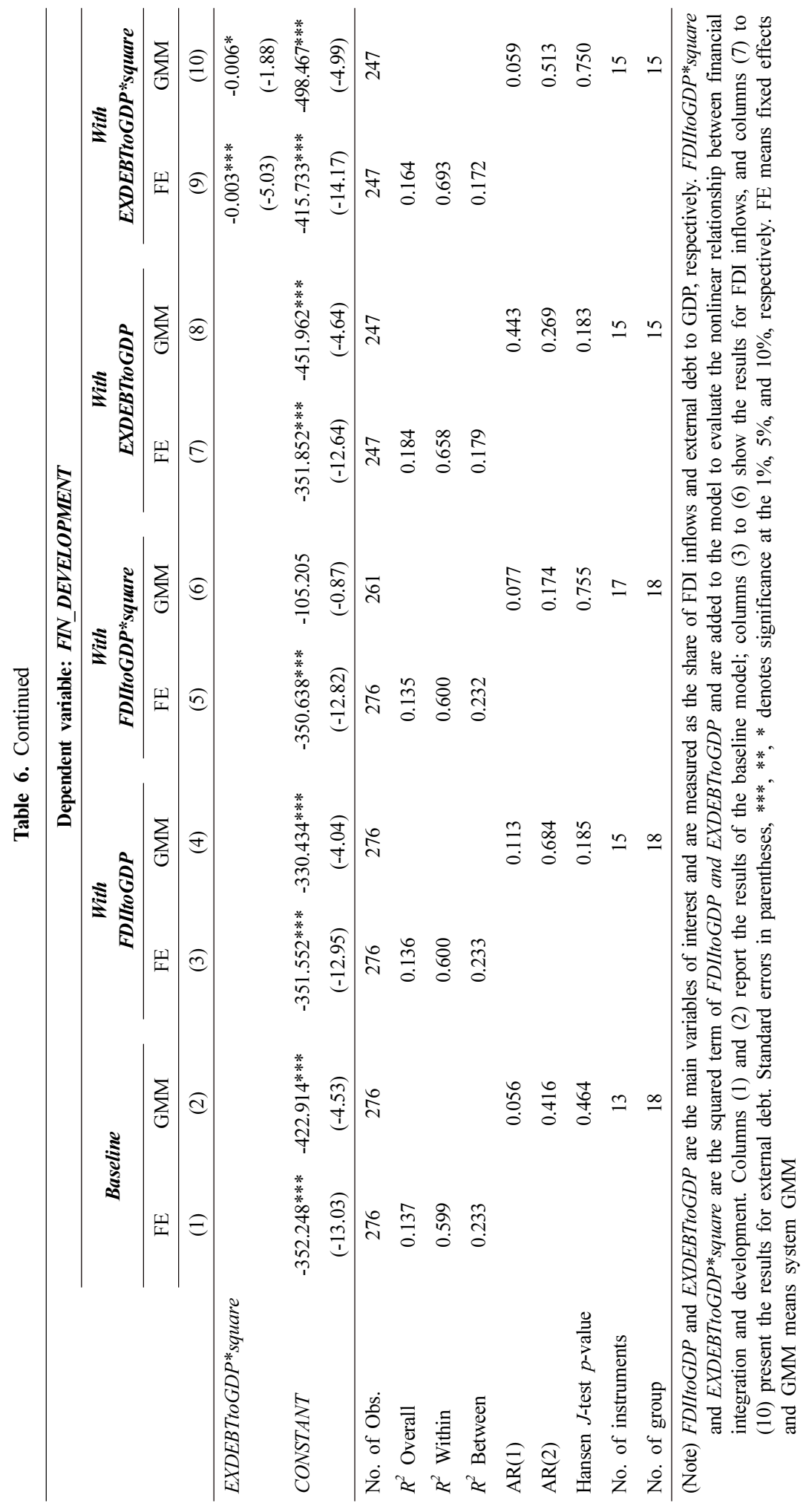


Alternatively, we use different measurements of financial development and integration. Specifically, we employ financial depth (FIN_DEPTH), which is measured by the ratio of aggregate private domestic credit from deposit banks and financial institutions to GDP. This measurement has been widely used as a proxy for financial development (King and Levine 1993, Asongu and De Moor 2016). For financial integration, we follow the construction of Lane and MilesiFerretti (2017) to calculate a financial integration index as a share of the aggregate stock of external assets and liabilities to GDP. The corresponding results are shown in Table 7.

Table 7. Robustness check: Other measurements of financial integration and development

\begin{tabular}{|c|c|c|c|c|c|c|}
\hline & \multicolumn{6}{|c|}{ Dependent variable: $F I N \_D E P T H$} \\
\hline & \multicolumn{2}{|c|}{ Baseline } & \multicolumn{2}{|c|}{ With FILANE } & \multicolumn{2}{|c|}{ With FILANE*square } \\
\hline & FE & GMM & FE & GMM & $\mathrm{FE}$ & GMM \\
\hline & (1) & (2) & (3) & (4) & (5) & (6) \\
\hline \multirow[t]{2}{*}{ TRADE OPENNESS } & $0.094 * *$ & $0.479 * *$ & $0.115^{* *}$ & 0.221 & $0.115^{* *}$ & 0.138 \\
\hline & (1.99) & $(2.01)$ & $(2.46)$ & $(0.94)$ & $(2.44)$ & $(0.61)$ \\
\hline \multirow[t]{2}{*}{ INFLATION } & 0.085 & -0.285 & 0.074 & $-0.313^{*}$ & 0.074 & $-0.353^{* *}$ \\
\hline & $(0.92)$ & $(-1.29)$ & $(0.87)$ & $(-1.54)$ & $(0.87)$ & $(-1.90)$ \\
\hline \multirow[t]{2}{*}{$G D P P C$} & $33.270^{* * *}$ & $41.053 * * *$ & $27.232 * * *$ & $36.970 * * *$ & $27.347 * * *$ & $34.181 * * *$ \\
\hline & (13.78) & $(5.17)$ & (11.09) & $(4.04)$ & $(10.23)$ & $(3.61)$ \\
\hline \multirow[t]{2}{*}{$I Q$} & 3.819 & -8.125 & -0.991 & -4.511 & -1.002 & 2.344 \\
\hline & $(0.90)$ & $(-0.51)$ & $(-0.23)$ & $(-0.29)$ & $(-0.23)$ & $(0.15)$ \\
\hline \multirow[t]{2}{*}{ FILANE } & & & $8.189 * * *$ & $6.201^{*}$ & $7.853 * *$ & $12.721 * *$ \\
\hline & & & $(7.43)$ & $(1.50)$ & $(2.42)$ & $(1.99)$ \\
\hline \multirow[t]{2}{*}{ FILALNE*square } & & & & & 0.040 & $-1.092 *$ \\
\hline & & & & & $(0.11)$ & $(-1.85)$ \\
\hline \multirow[t]{2}{*}{ CONSTANT } & $-154.496^{* * *}$ & $-259.307 * * *$ & $-123.351 * * *$ & $-213.619 * *$ & $-123.905 * * *$ & $-185.680 * *$ \\
\hline & $(-7.25)$ & $(-3.18)$ & $(-5.59)$ & $(-2.38)$ & $(-5.46)$ & $(-2.05)$ \\
\hline No. of Obs. & 432 & 432 & 330 & 330 & 330 & 330 \\
\hline$R^{2}$ Overall & 0.443 & & 0.428 & & 0.429 & \\
\hline$R^{2}$ Within & 0.352 & & 0.457 & & 0.457 & \\
\hline$R^{2}$ Between & 0.471 & & 0.438 & & 0.439 & \\
\hline $\operatorname{AR}(1)$ & & 0.001 & & 0.005 & & 0.007 \\
\hline $\operatorname{AR}(2)$ & & 0.155 & & 0.224 & & 0.147 \\
\hline Hansen $J$-test $p$-value & & 0.437 & & 0.700 & & 0.884 \\
\hline No. of instruments & & 7 & & 9 & & 11 \\
\hline No. of groups & & 24 & & 18 & & 18 \\
\hline
\end{tabular}

(Note) Financial integration index (FILANE), which is calculated in line with Lane and Milesi-Ferretti (2017), is the main variable of interest. FILANE* square is the squared term of FILANE and is added to the model to evaluate the nonlinear relationship between financial integration and development. Columns (1) and (2) report the results of the baseline model; columns (3) and (4) show the results for our mainstream model; and columns (5) and (6) present the results with squared term. Standard errors in parentheses, ***, **,* denotes significance at the $1 \%, 5 \%$, and $10 \%$, respectively. FE means fixed effects and GMM means system GMM 
Results obtained from both robustness tests confirm our main findings in Table 5. The detailed outcomes are not presented here to conserve space but are available upon request.

\section{B. Threshold analyses}

\section{Trade openness as a threshold}

Table 8 presents the PTR results determining the thresholds of trade openness that allow for the positive relationship between financial integration and development. Columns (1) and (2) report the results of the TPR with FDIItoGDP as a measure of financial integration, whereas columns (3) and (4) show the results for EXTDEBTtoGDP

In columns (1) and (2), PTR results indicate that at the preliminary stage of trade openness, successive FDI inflows could robustly enhance financial development. However, once trade openness surpasses the threshold of $140.437 \%$ as a share of GDP, this effect becomes negative and insignificant. $F$-test results show that the single-threshold model is appropriate at a significance level of $5 \%$. The result is consistent with the few studies that discovered a positive impact of FDI inflows on stock-market developments (Raza et al. 2015, Abzari et al. 2011, Adam and Tweneboah 2009, El-Wassal 2005).

Regarding external debt as a measurement of financial integration, similar threshold effects are reported. From columns (3) and (4), it is evident that only the single-threshold model is significantly reliable. The PTR model indicates that the impact of external debt always exerts a positive impact on financial development when countries open their domestic markets. Interestingly, when trade openness reaches a threshold of $144.615 \%$, the magnitude of positive effect becomes robustly stronger. In short, opening up the domestic market could be a driving force for the financial sector to benefit from its integration into the world.

\section{GDP per capita as a threshold}

To examine the contribution of financial integration to financial development conditioned on the level of GDP capital a country needs to reach, we further employ the PTR method using the logarithm of GDPPC as a threshold variable. Results from these estimations are reported in Table 9. Columns (1) and (2) show the results of PTR with FDIItoGDP as a measure of FI; and columns (3) and (4) show the results for EXTDEBTtoGDP.

From columns (1) and (2), the two GDPPC thresholds are 1,880.33 US dollars ( $\ln G D P P C$ $=7.5392)$ and $36,497.53$ US dollars $(\ln G D P P C=10.505)$. When the GDPPC of the economy remains below the standard, the effect of FDI inflows on financial development is negative and statistically significant. After achieving the lower GDPPC threshold, the impact becomes positive and statistically significant. It is clear that all countries in our sample display GDP per capita higher than the lower bound, meaning that they have all the prerequisites to realize 
Table 8. Panel threshold regression with trade openness as a threshold variable

\begin{tabular}{|c|c|c|c|c|}
\hline & \multicolumn{4}{|c|}{ Trade Openness as threshold - Dependent variable: FIN_DEVELOPMENT } \\
\hline & \multicolumn{2}{|c|}{ FDIItoGDP as FI } & \multicolumn{2}{|c|}{ EXTDEBTtoGDP as FI } \\
\hline & Single threshold & Double threshold & Single threshold & Double threshold \\
\hline & (1) & (3) & (1) & (2) \\
\hline \multirow[t]{2}{*}{ CONSTANT } & $-429.703 * * *$ & $-406.576^{* * *}$ & $-306.468 * * *$ & $-335.949 * * *$ \\
\hline & $(-12.12)$ & $(-10.94)$ & $(-11.18)$ & $(-12.37)$ \\
\hline \multirow[t]{2}{*}{ TRADE OPENNESS } & $0.578 * * *$ & $0.496 * * *$ & $0.176^{* * *}$ & 0.101 \\
\hline & $(8.20)$ & $(6.07)$ & $(2.67)$ & $(1.54)$ \\
\hline \multirow[t]{2}{*}{ INFLATION } & $0.568 * *$ & $0.491 * *$ & 0.228 & 0.164 \\
\hline & $(2.46)$ & $(2.12)$ & $(1.31)$ & $(0.98)$ \\
\hline \multirow[t]{2}{*}{$G D P P C$} & $58.723 * * *$ & $56.978 * * *$ & $47.027 * * *$ & $52.049 * * *$ \\
\hline & $(15.37)$ & $(14.61)$ & $(14.30)$ & (15.48) \\
\hline \multirow[t]{2}{*}{$I Q$} & $23.842 * * *$ & $22.441 * * *$ & 0.596 & 6.178 \\
\hline & $(3.05)$ & $(2.87)$ & $(0.14)$ & $(1.44)$ \\
\hline \multicolumn{5}{|l|}{ FIxThreshold } \\
\hline \multirow[t]{2}{*}{0} & $264.432 * * *$ & $257.524 * * *$ & $0.160 * * *$ & $-0.859 * * *$ \\
\hline & $(5.10)$ & (4.99) & $(4.03)$ & $(-3.60)$ \\
\hline \multirow[t]{2}{*}{1} & -0.051 & -0.068 & $1.776^{* * *}$ & $0.122 * * *$ \\
\hline & $(-0.21)$ & $(-0.28)$ & $(8.95)$ & $(3.12)$ \\
\hline \multirow[t]{2}{*}{2} & & $2.217^{*}$ & & $1.723 * * *$ \\
\hline & & $(1.86)$ & & $(9.04)$ \\
\hline Number of Obs. & 220 & 220 & 220 & 220 \\
\hline$R^{2}$ Overall & 0.451 & 0.463 & 0.387 & 0.425 \\
\hline$R^{2}$ Within & 0.632 & 0.639 & 0.731 & 0.754 \\
\hline$R^{2}$ Between & 0.429 & 0.440 & 0.263 & 0.307 \\
\hline \multicolumn{5}{|c|}{ Thresholds and threshold effects } \\
\hline Threshold-1 & 140.437 & 140.437 & 144.615 & 144.615 \\
\hline Threshold-2 & & 20.041 & & 50.180 \\
\hline RSS & 62700 & 61100 & 42700 & 39100 \\
\hline MSE & 316.418 & 308.459 & 215.463 & 197.260 \\
\hline$F$-stat & 28.83 & 5.110 & 67.91 & 18.27 \\
\hline$P$-value & 0.036 & 0.853 & 0.008 & 0.153 \\
\hline
\end{tabular}

(Note) FDIItoGDP and EXDEBTtoGDP are the main variable of interest and are measured as the share of FDI inflows and external debt to GDP, respectively. FI stands for financial integration. Panel threshold regression (PTR) is employed to examine prerequisites that a country needs to achieve before the rewards of financial integration are materialized. Trade openness (TO) is employed as a threshold variable. Columns (1) and (2) report the results of the PTR with FDIItoGDP as a measure of FI; and columns (3) and (4) show the results for external debt. Standard errors in parentheses, $* * *, * *, *$ denotes significance at the $1 \%, 5 \%$, and $10 \%$, respectively.

the advantages of FDI inflows on financial development

External debt shows interesting findings. Results from columns (3) and (4) indicate that at substandard GDP per capita, the effect of external debt on financial development is negative. 
Table 9. Threshold panel regression with per capita GDP as a threshold variable

\begin{tabular}{|c|c|c|c|c|}
\hline & \multicolumn{4}{|c|}{ GDPPC as threshold - Dependent variable: FIN_DEVELOPMENT } \\
\hline & \multicolumn{2}{|c|}{ FDIItoGDP as FI } & \multicolumn{2}{|c|}{ EXTDEBTtoGDP as FI } \\
\hline & Single threshold & Double threshold & Single threshold & Double threshold \\
\hline & (1) & (2) & (3) & (4) \\
\hline \multirow[t]{2}{*}{ CONSTANT } & $-368.152 * * *$ & $-324.513 * * *$ & $-198.992 * * *$ & $-342.701 * * *$ \\
\hline & $(-10.16)$ & $(-8.75)$ & $(-6.49)$ & $(-10.05)$ \\
\hline \multirow[t]{2}{*}{ TRADE OPENNESS } & $0.561 * * *$ & $0.479 * * *$ & $0.107^{*}$ & 0.031 \\
\hline & $(7.95)$ & $(6.66)$ & $(1.67)$ & $(0.54)$ \\
\hline \multirow[t]{2}{*}{ INFLATION } & $0.453 *$ & $0.398^{*}$ & 0.114 & 0.043 \\
\hline & (1.96) & $(1.77)$ & $(0.69)$ & $(0.29)$ \\
\hline \multirow[t]{2}{*}{$G D P P C$} & $52.304 * * *$ & $48.445^{* * *}$ & $36.170 * * *$ & $53.175 * * *$ \\
\hline & (13.33) & (12.28) & $(10.32)$ & (13.48) \\
\hline \multirow[t]{2}{*}{$I Q$} & $18.208^{* *}$ & $17.977 * *$ & -5.735 & -3.660 \\
\hline & $(2.33)$ & $(2.37)$ & $(-1.39)$ & $(-0.99)$ \\
\hline \multicolumn{5}{|l|}{ FIxThreshold } \\
\hline \multirow[t]{2}{*}{0} & -0.074 & $-5.304 * * *$ & $-0.747 * * *$ & $-0.408 * * *$ \\
\hline & $(-0.30)$ & $(-3.72)$ & $(-7.80)$ & $(-4.15)$ \\
\hline \multirow[t]{2}{*}{1} & $10.213 * * *$ & 0.023 & $0.242 * * *$ & $0.520 * * *$ \\
\hline & $(4.93)$ & $(0.09)$ & $(6.27)$ & $(9.97)$ \\
\hline \multirow[t]{2}{*}{2} & & $10.820 * * *$ & & $0.147 * * *$ \\
\hline & & $(5.37)$ & & $(3.96)$ \\
\hline Number of Obs. & 220 & 220 & 220 & 220 \\
\hline$R^{2}$ Overall & 0.392 & 0.396 & 0.206 & 0.196 \\
\hline$R^{2}$ Within & 0.630 & 0.654 & 0.760 & 0.808 \\
\hline$R^{2}$ Between & 0.361 & 0.363 & 0.079 & 0.081 \\
\hline \multicolumn{5}{|c|}{ Thresholds and threshold effects } \\
\hline Threshold-1 & 10.505 & 10.505 & 8.017 & 8.017 \\
\hline Threshold-2 & & 7.5392 & & 9.1648 \\
\hline RSS & 64000 & 58600 & 38000 & 30400 \\
\hline MSE & 323.118 & 295.760 & 191.980 & 153.589 \\
\hline$F$-stat & 24.12 & 18.310 & 100.440 & 49.490 \\
\hline$P$-value & 0.330 & 0.273 & 0.000 & 0.022 \\
\hline
\end{tabular}

(Note) FDIItoGDP and EXDEBTtoGDP are the main variable of interest and are measured as the share of FDI inflows and external debt to GDP, respectively. FI stands for financial integration. Panel threshold regression (PTR) is employed to examine prerequisites that a country needs to achieve before the rewards of financial integration materialized. Per capita GDP $(G D P P C)$ in logarithm form is employed as a threshold variable. Columns (1) and (2) report the results of the PTR with FDIItoGDP as a measure of FI; and columns (3) and (4) show the results for external debt. Standard errors in parentheses, ***,**,* denotes significance at the $1 \%, 5 \%$, and $10 \%$, respectively

However, it turns positive if the economy accomplishes the GDPPC threshold of 3,032.07 US dollars $(\ln G D P P C=8.017)$. Beyond the upper threshold of 9,554.81 US dollars $(\ln G D P P C$ $=9.1648)$, the impact remains positive and significant, but the magnitude of the effect weakens 
evidently. All countries in our sample have already achieved the "required" threshold for financial sector to benefit from its openness. Specifically, the GDP per capita of countries in our sample are all higher than the lower threshold (3,032.07 US dollars). The results of the $F$-test show that both the single-threshold and double-threshold models are statistically significant.

\section{Institutional quality as a threshold}

We repeat the PTR using institutional quality as a threshold variable. Columns (1) and (2) show the estimation outcomes with FDIItoGDP as a measure of FI, whereas columns (3) and (4) reveal the results for EXTDEBTtoGDP.

Regarding FDI inflows, it is clear from columns (1) and (2) that at the initial stage when average institutional score is lower, FDI inflows act as deterrence to the development of financial system. However, when an improvement is noted in the institutional quality is improved and it reaches a threshold of 0.258 , the developmental effect of inward FDI turns positive and significant. The magnitude of this impact may become weaker when the upper threshold of 0.279 is achieved. This finding agrees with some prior studies (David et al. 2015) that showed that financial integration might be more important in countries with better institutional quality.

Regarding external debt, the PTR shows that when institutional quality is improved, cross-border debt liabilities consistently impose positive impacts on financial development. However, the strength and significance of this effect are contingent on the level of institutional quality. Specifically, the effect of financial openness on financial development is found to be significant if the institution quality score is below the lower threshold (-0.629) or above the upper threshold (0.154). 
Table 10. Threshold panel regression with institutional quality as a threshold variable

\begin{tabular}{|c|c|c|c|c|}
\hline & \multicolumn{4}{|c|}{ Institutional Quality as threshold - Dependent variable: FIN_DEVELOPMENT } \\
\hline & \multicolumn{2}{|c|}{ FDIItoGDP as FI } & \multicolumn{2}{|c|}{ EXTDEBTtoGDP as FI } \\
\hline & Single threshold & Double threshold & Single threshold & Double threshold \\
\hline & (1) & (2) & (3) & (4) \\
\hline \multirow[t]{2}{*}{ CONSTANT } & $-419.808 * * *$ & $-432.909 * * *$ & $-445.450 * * *$ & $-492.366^{* * *}$ \\
\hline & $(-11.44)$ & $(-12.12)$ & $(-15.75)$ & $(-18.23)$ \\
\hline \multirow[t]{2}{*}{ TO } & $0.564 * * *$ & $0.602 * * *$ & $0.344 * * *$ & $0.406^{* * *}$ \\
\hline & (7.72) & $(8.44)$ & $(5.31)$ & $(6.75)$ \\
\hline \multirow[t]{2}{*}{$I N F$} & $0.491^{* *}$ & $0.455^{*}$ & 0.055 & -0.130 \\
\hline & $(2.06)$ & $(1.96)$ & $(0.28)$ & $(-0.72)$ \\
\hline \multirow[t]{2}{*}{$G D P P C$} & $58.073 * * *$ & $59.312 * * *$ & $62.749 * * *$ & $66.943 * * *$ \\
\hline & $(14.65)$ & $(15.39)$ & $(17.53)$ & (19.98) \\
\hline \multirow[t]{2}{*}{$I Q$} & 9.639 & 5.809 & $16.593 * * *$ & -0.087 \\
\hline & (1.11) & $(0.68)$ & $(3.31)$ & $(-0.02)$ \\
\hline \multicolumn{5}{|l|}{ FIxThreshold } \\
\hline \multirow[t]{2}{*}{0} & -0.232 & -0.244 & $0.583 * * *$ & $0.541 * * *$ \\
\hline & $(-0.88)$ & $(-0.96)$ & $(7.06)$ & (7.11) \\
\hline \multirow[t]{2}{*}{1} & $2.370^{* * *}$ & $11.426^{* * *}$ & 0.018 & 0.001 \\
\hline & $(2.92)$ & $(4.71)$ & $(0.37)$ & $(0.03)$ \\
\hline \multirow[t]{2}{*}{2} & & $1.389 *$ & & $0.564 * * *$ \\
\hline & & $(1.72)$ & & $(5.78)$ \\
\hline Number of Obs. & 220 & 220 & 220 & 220 \\
\hline$R^{2}$ Overall & 0.387 & 0.380 & 0.328 & 0.382 \\
\hline$R^{2}$ Within & 0.604 & 0.630 & 0.695 & 0.744 \\
\hline$R^{2}$ Between & 0.360 & 0.348 & 0.220 & 0.276 \\
\hline \multicolumn{5}{|c|}{ Thresholds and threshold effects } \\
\hline Threshold-1 & 0.258 & 0.258 & -0.629 & -0.629 \\
\hline Threshold-2 & & 0.279 & & 0.154 \\
\hline RSS & 68400 & 63900 & 48400 & 40600 \\
\hline MSE & 345.501 & 322.954 & 244.634 & 204.954 \\
\hline$F$-stat & 9.73 & 13.820 & 36.200 & 38.330 \\
\hline$P$-value & 0.539 & 0.192 & 0.119 & 0.029 \\
\hline
\end{tabular}

(Note) FDIItoGDP and EXDEBTtoGDP are the main variable of interest and are measured as the share of FDI inflows and external debt to GDP, respectively. FI stands for financial integration. Panel threshold regression (PTR) is employed to examine prerequisites that a country needs to achieve before the rewards of financial integration materialized. Institutional Quality (IQ) is employed as a threshold variable. Columns (1) and (2) report the results of the PTR with FDIItoGDP as a measure of FI; and columns (3) and (4) show the results for external debt. Standard errors in parentheses, $* * *, * * *$ denotes significance at the $1 \%, 5 \%$, and $10 \%$, respectively 


\section{Discussion and Conclusion}

In this study, we examined the developmental influence of financial openness on the financial market and evaluated whether this effect varied with different threshold levels of national development. Using a comparatively comprehensive dataset covering 34 countries from the East Asian and Pacific region during the period 1996 2017, we provided empirical evidence showing the existence of a significant inverted U-shaped relationship between financial integration and development. This finding is mostly consistent across different empirical methodologies, even when controlling for endogeneity. In addition, we found a threshold of external debt of $87.8 \%$ of GDP, above which the globalization of the financial market fails to boost its development. This suggests that more integrated financial systems are not always better, and such a system can harm financial development after a certain point.

We also assessed the existence of national conditions for a financial market to benefit from its global integration. Our study revealed that for FDI inflows to facilitate advances in the financial market, the trade openness of a country should be below $140.437 \%$. The rewards of external debt flows on financial development were positive regardless of thresholds; however, the magnitude was dependent on the level of trade openness. We further found that the impact of cross-border debt on financial development turned positive when GDP per capita surpassed 3,032.07 US dollars. However, this effect became less pronounced when the country reached 9,554.81 US dollars or more in GDP per capita. The effect of financial openness on financial development was found to be positively significant when institutional quality was below the lower threshold (-0.629) or over the upper threshold (0.154).

The analyses of these national economic thresholds suggest some important considerations for several policies toward more sustainable financial development in the examined countries. The main policy implication from our findings is that the threshold levels of certain variables are important determinants of the relationship between financial integration and development. Countries pursuing liberalization policies should prioritize these national developments in advance to understand what levels or thresholds are required for their economies to benefit from financial globalization.

As our study focused on the East Asian and Pacific region, our conclusions do not necessarily hold true for all countries. Given a wide divergence in terms of national conditions (e.g., institutional quality, financial reform, and regional details), country-specific studies are desirable. Furthermore, our financial development measures were constructed mainly from banking sector indicators. Because the equity market also plays an important role in allocating funds and firms increasingly rely on equity finance, especially in developed countries, it is pivotal to evaluate this aspect as regards the financial integration and development nexus. Moreover, owing to the high correlation among financial measures, the interactions between variables are interesting 
subjects. Because of data availability, the number of countries in our research was relatively limited. Therefore, a study with a larger sample size is needed before the results can be considered conclusive. We leave these issues for future research.

\section{References}

Abzari, M., Fatemeh, Z., and Sharif, S. E. (2011). "Analyzing the link between financial development and foreign direct investment among D-8 group of countries." International Journalof Economics and Finance, 3, 148-156.

Adam, A. M., and George. T. (2009). "Foreign direct investment and stock market development: Ghana's evidence." International Research Journal of Finance and Economics, 26, 178-185.

Allen, F., Carletti, E., Cull, R. et al. (2012). Resolving the African financial development gap: Cross-country comparisons and a within-country study of Kenya. NBER Working Paper No. 18013, Cambridge, MA.

Arellano, M., and Bover, O. (1995). "Another look at the instrumental variable estimation of error component model." Journal of Econometrics, 68, no. 1, 29-52.

Arestis, P., Chortareas, G., and Magkonis, G. (2014). "The financial development and growth nexus: A meta-analysis." Journal of Economic Surveys, 29, no. 3, 549-565.

Asongu, S. A., and De Moor, L. D. (2016). "Financial globalization dynamic thresholds for financial development: Evidence from Africa." European Journal of Development Research, 29, 192-212.

Ashraf, B. N. (2018). "Do trade and financial openness matter for financial development? Bank-level evidence from emerging market economies." Research in International Business and Finance, 44, 434-458.

Baltagi, B. H., Demetriades, P. O., and Law, S. H. (2009). "Financial development and openness: evidence from panel data." Journal of Development Economics, 89, 285-296.

Beck, T., Demirgüç-Kunt, A., and Levine. R. (2000a). "A new database on financial development and structure." World Bank Economic Review, 14, 597-605.

Beck, T., Levine, R., and Loayza, N. (2000b). "Finance and the sources of growth." Journal of Financial Economics, 58, no. 1-2, 261-300

Bond, S., Hoeffler, A., and Tample, J. (2001). GMM Estimation of empirical growth models. Oxford: University of Oxford.

Boyd, J. H., Levine, R., and Smith, B. D. (2001). "The impact of inflation on financial sector performance." Journal of Monetary Economics, 47, 221-248.

Boubakri, S., and Guillaumin, C. (2015). "Regional integration of the East Asian stock market: an empirical assessment." Journal of International Money Finance, 57, 136-60.

Blundell, R., and Bond, S. (1998). "Initial conditions and moment restrictions in dynamic panel data models." Journal of Econometrics, 87, no. 1, 115-143.

Chinn, M. D., and Ito, H. (2006). "What matters for financial development? Capital controls, institutions, and interactions." Journal of Development Economics, 81, 163-92. 
David, A.C., Mlachila, M., and Moheeput, A. (2015). "Does international integration matter for financial development in Africa?" Applied Economics, 47, no. 15, 1525-1549.

Demetriades, P., and Law, S. H. (2006). "Finance, institutions and economic development." International Journal of Finance and Economics, 11, no. 3, 245-260.

Didier, T., Llovet, R., and Schmukler, S. L. (2017). "International financial integration of East Asia and Pacific." Journal of The Japanese and International Economies, 44, 52-66.

Do, Q. T., and Levchenko, A. A. (2004). Trade and financial development. World Bank Policy Research Working Paper No. 3347.

El-Wassal, K. (2005). "Understanding the growth in emerging stock markets." Journal of Emerging Market Finance, 4, 227-261.

Fry-McKibbin, R., Hsiao, CY-L., and Martin, V. L. (2018). "Global and regional financial integration in East Asia and the ASEAN." North American Journal of Economics and Finance, 46, 202-221.

Hansen, B. E., (1999). "Threshold effects in non-dynamic panels: estimation, testing, and inference." Journal of Econometrics, 93, no. 2, 345-368.

Hansen, B. E. (2000). "Sample splitting and threshold estimation." Econometrica, 68, 575-604.

Hauner, D., Prati, A., and Bircan, C. (2013). "The interest group theory of financial development: evidence from regulation." Journal of Banking and Finance, 37, 895-906.

Jaffee, D., and Levonian, M. (2001). "Structure of banking systems in developed and transition economies." European Financial Management, 7, no. 2, 161-181.

King, R., and Levine. R. (1993). "Finance and growth: Schumpeter might be right." Quarterly Journal of Economics, 108, no. 3, 717-37.

Klein, M., and Olivei, G. (2008). "Capital account liberalization, financial depth, and economic growth." Journal of International Money and Finance, 27, 861-75.

Kose, M. A., Prasad, E. S., Rogoff, K. S., and Wei. S.-J. (2006). "Financial globalization: A reappraisal." IMF Staff Papers, 56, no. 1, 8-62.

Kose, M. A., Prasad, E., Rogoff, K., and Wei, S. J. (2009). "Financial globalization: A reappraisal." IMF Staff Papers, 56, 8-62.

Kose, M. A., Prasad, E. S., and Terrones, M. (2009a). "Does openness to international financial flows raise productivity growth?" Journal of International Money and Finance, 28, 554-80.

Kose, M. A., Prasad, E. S., and Taylor, A. D. (2011). "Threshold in the process of international financial integration." Journal of International Money and Finance, 30, no. 1, 147-79.

Lane, P. R., and Milesi-Ferretti, G. M. (2017). International Financial Integration in the Aftermath of the Global Financial Crisis. IMF Working Paper, No. WP/17/115. Available online: https://www.researchg ate.net/publication/317337467_International_Financial_Integration_in_the_Aftermath_of_the_Global_ Financial_Crisis (acessed on 13 May 2019).

Law, S. H., Azman-Saini, WNW., and Ibrahim, M. H. (2013). "Institutional quality thresholds and the finance-Growth nexus." Journal of Banking and Finance, 37, 5373-5381.

Law, S. H., and Singh, N. (2014). "Does too much finance harm economic growth?" Journal of Banking and Finance, 41, 36-44.

Levine, R. (2001). "International financial liberalization and economic growth.” Review of International 
Economics, 9, 688-701.

MacKinnon, J. G. (2002). "Bootstrap inference in econometrics." Canadian Journal of Economics, 35, 615-45.

Menya, K., Nazlioglu, S., and Wolde-Rufael, Y. (2014). "Financial development, trade openness and economic growth in African countries: New insights from a panel causality approach." Economic Modelling, 37, 386-94.

Mishkin, F. (2009). "Why we shouldn’t turn our backs on financial globalization," IMF Staff Papers, 56, 139-170.

Mody, A., and Murshid, A. P. (2005). "Growing up with capital flows." Journal of International Economics, 65 , no. 1, 249-266.

Odhiambo, N. M. (2008). "Financial depth, savings and economic growth in Kenya: A dynamic causal linkage." Economic Modelling, 25, no. 4, 704-13.

Obstfeld, M. (2008). International finance and growth in developing countries: what have we learned? Working Paper, Commission on Growth and Development, World Bank, No. 34, Washington DC.

Ozkok, Z (2015). "Financial openness and financial development: An analysis using indices." International Review of Applied Economics, 29, no. 5, 620-649.

Quinn, D. (2003). "Capital account liberalization and financial globalization, 1890-1999: A synoptic view." International Journal of Finance and Economics, 8, no. 3, 189-204.

Rajan, R. G., and Zingales, L. (2003). "The great reversals: the politics of financial development in the twentieth century." Journal of Financial Economics, 69, 5-50.

Raza, S. A., Syed, T. J., Sahar, A., and Mohd, Z. A. K. (2015). "Is stock market sensitive to foreign capital inflows and economic growth? Evidence from Pakistan." Journal of Chinese Economic and Foreign Trade Studies, 8, 142-164.

Rodrik, D., and Subramanian, A. (2009). "Why did financial globalization disappoint?" IMF Staff Papers, 56, no. $1,112-138$.

Roodman, D. (2009). "How to do xtabond2: An introduction to difference and system GMM in Stata." Stata Journal, 9, no. 1, 86-136.

Stultz, R., (1999). "Globalization, corporate finance and the cost of capital." Journal of Applied Corporate Finance, 12, no. 3, 8-25.

T.-H. Le, Kim, J., and Lee, M. (2017). "Institutional quality, trade openness, and financial sector development in Asia: An empirical investigation.” Emerging Markets Finance and Trade, 52, 1047-1059

World Bank. (2007). World Development Indicators. Washington, DC: International Bank for Reconstruction and Development. The World Bank Press.

Wold Bank, (2017). Global Financial Development Report: Global Banking. Accessed on 10 April 2019 https://www.worldbank.org/en/publication/gfdr

Yilmazkuday, H. (2011). "Thresholds in the finance-growth nexus: A cross-country analysis." World Bank Economic Review, 25, no. 2, 278-295. 
Appendix 1. Countries included in the study

\begin{tabular}{llll}
\hline Australia & Kiribati & Myanmar & Taiwan \\
\hline Brunei Darussalam & Democratic People's Republic of Korea & Nauru & Thailand \\
Cambodia & Republic of Korea (South Korea) & New Zealand & Timor-Leste \\
China & Lao People's Democratic Republic & Palau & Tonga \\
Fiji & Macao & Papua New Guinea & Tuvalu \\
Guam & Malaysia & Philippines & Vanuatu \\
Hong Kong & Marshall Islands & Samoa & Vietnam \\
Indonesia & Micronesia, Fed. Sts. & Singapore & \\
Japan & Mongolia & Solomon Islands & \\
\hline
\end{tabular}

Appendix 2. Countries included in panel threshold regressions

\begin{tabular}{ll}
\hline Cambodia & Mongolia \\
Fiji & Philippines \\
Australia & Solomon Islands \\
Indonesia & Thailand \\
Japan & Tonga \\
Republic of Korea (South Korea) & Vanuatu \\
Malaysia & Vietnam
\end{tabular}


Appendix 3. Variable definitions and sources

\begin{tabular}{|c|c|c|}
\hline Variables & Variable definitions & Sources \\
\hline \multirow[t]{5}{*}{ FIN_DEVELOPMENT } & $\begin{array}{l}\text { Financial development index constructed from the following four } \\
\text { financial indicators (using PCA): }\end{array}$ & \\
\hline & - Broad money supply (\% of GDP) & World Bank (FDSD) \\
\hline & - Liquid liabilities (\% of GDP) & World Bank (FDSD) \\
\hline & - Private domestic credit from financial institutions ( $\%$ of GDP) & World Bank (FDSD) \\
\hline & - Private domestic credit from deposit banks ( $\%$ of GDP) & World Bank (FDSD) \\
\hline \multirow[t]{3}{*}{$F I$} & Financial integration, measured interchangeably via two indicators: & \\
\hline & - FDI net inflows (\% of GDP) & World Bank (WDI) \\
\hline & - External debt (\% of GDP) & World Bank (WDI) \\
\hline \multirow[t]{3}{*}{ FILane } & $\begin{array}{l}\text { Financial Integration, constructed via two finance indicators, } \\
\text { following the construction of Lane and Milesi-Ferretti (2017) }\end{array}$ & \\
\hline & - Total foreign assets & Lane and Milesi-Ferretti (2017) \\
\hline & - Total foreign liabilities & Lane and Milesi-Ferretti (2017) \\
\hline PUB_INVESTMENT & Gross public investment ( $\%$ of GDP) & World Bank (WDI) \\
\hline INFLATION & Consumer price index (annual \%) & World Bank (WDI) \\
\hline FOREIGN AID & Total net official development assistance ( $\%$ of GDP) & World Bank (WDI) \\
\hline TRADE OPENNESS & Trade imports plus exports in commodities ( $\%$ of GDP) & World Bank (WDI) \\
\hline$G D P P C$ & $\begin{array}{l}\text { Logarithm of GDP per capital, purchasing-power parity (current } \\
\text { international US dollar) }\end{array}$ & World Bank (WDI) \\
\hline POP_DENSITY & People per $\mathrm{km}^{2}$ of land area & World Bank (WDI) \\
\hline$I Q$ & $\begin{array}{l}\text { Institutional quality, constructed by simple averaging of six } \\
\text { World Bank governance indicators }\end{array}$ & World Bank (GI) \\
\hline
\end{tabular}

(Note) WDI: World Bank Development Indicators. FDSD: Financial Development and Structure Database. GI: Governance Indicators. 